\section{Valency-changing derivations in Dulong/Rawang}

RANDY J. LAPOLLA

\section{Introduction}

Dulong/Rawang is a Tibeto-Burman language spoken on both sides of the China/Myanmar (Burma) border just south and east of Tibet. In China, the people who speak this language for the most part live in Gongshan county of Yunnan province, and belong either to what is known as the 'Dulong' nationality (pop. 5,816 according to the 1990 census), or to one part (roughly 6,000 people) of the $\mathrm{Nu}$ nationality (those who live along the upper reaches of the $\mathrm{Nu}$ River - the part of the Salween within China). Another subgroup of the Nu people, those who live along the lower reaches of the Nu River (in China), speak a language called 'Anung' which seems to be the same as, or closely related to, the Kwinpang dialect spoken in Myanmar, so should also be conrelated to, the Kwinpang dialect spoken a dialect of Dulong/Rawang. ${ }^{1}$ Within Myanmar, the people who speak the Dulong/Rawang language (possibly up to 100,000 people) live in northern Kachin State, particularly along the Mae Hka ('Nmai Hka) and Maeli Hka (Mali Hka) River valleys. In the past they had been called 'Hkanung' or 'Nung', and have often been considered to be a subgroup of the Kachin (Jinghpaw). Among themselves they have had no general term for the entire group; they use their respective clan names to refer to themselves. This is true also of those who live in China, although these people have accepted the

Id like to thank all those who gave me comments on the draft of this chapter presented at the Td like to editor Internis volume and Tasaku Tsunoda for comments on the written version.

1 the volume and Tasaku Tsunodion of the Anung language. See Lo (1945), Sun (1982), Liu See Sun (1988) for a briat descrions of Dulong dialects. Bamard (1988), Dai et al. (19) (1934) is a description of the Wresented there seem to have been influenced by the working latal stops, and the structures prow) used for the elicitation. exonym 'Dulong' (or 'Taron', or 'Trung'), a name they were given because they mostly live in the valley of the Dulong (Taron/Trung) River. ${ }^{2}$

Recently, speakers of this language in Myanmar have begun a movement to use the name /raway/ (spelled 'Rvwang' in the Rawang orthographies, but 'Rawang' for this chapter) to represent all of its speakers. This name is said to be an abbreviation for nmèxàng 'middle river', as the Rawang people are said to have come down from the north along the middle river (the Mekong). The speakers in China, though, continue to use the name 'Dulong'. For this reason I refer to the language as Dulong/Rawang. ${ }^{3}$ In this chapter, I will be using data of the Mvtwang (Mvt River) dialect, which is considered the most central of those dialects in Myanmar and so has become something of a standard for writing ${ }^{4}$ and intergroup communication, though most of the phenomena we will be discussing are general to dialects in both China and Myanmar.' I will use the short form 'Rawang' in referring to this dialect.

\section{Verb classes}

In Rawang there are three classes of verb: intransitives, which can be used transitively only when they take valency-increasing morphological marking

The name 'Nung' - 'Anung' (< Rawang Neng) seems to be related to one of the Rawang names for the Salween, Tinòng 'Brown River', a place where the Rawang people are said to have settled for quite some time before moving further west. In the past, the Dulong River, particularly the upper stretches, was known in Chinese as the Qiu River, and the Dulong people were known as the Qiu, Qiuzi, Qiupa or Qiao.

The actual number of dialects of Dulong/Rawang that exist and the relationships among them still need to be worked out, but it seems there are at least seven major dialects: Mvtwang Wvdamkong, Longmi, Dvru (Ganung), Dulong, Tangsarr and Kwinpang (Anung). Within the Dulong dialect it is also possible to distinguish at least four subvarieties: First Township, Third Township. Fourth Township and Nujiang Dulong. The differences among these subvarietie are rather minor, and so all are mutually intelligible. The dialect picture is actually not neatly divided between Chinese and Myanmar dialects, as Third Township Dulong and Dvru (spoke in Myanmar) are both very conservative phonologically, while the First Township, Fourth in Myanmar) are both very conservative phonologically, while the First Township, Fourth in Myanmar.

* A system of writing using the Roman alphabet and a few other symbols was developed by the American missionary Robert H. Morse (see Morse 1963 for an analysis of Rawang phonoAmerican missionary Robert H. Morse (see Morse 1963 for an analysis of Rawang phonology), and is in common use among the Rawang people. This system will be used in this chapter. Most letters represent the standard pronunciations of English, except that $i=[1], v=[\mathrm{a}]$ $a=[\mathrm{o}], \sigma=[\mathrm{u}], q=[\mathrm{R}]$ and $c=[\mathrm{s}]$ or $[\mathrm{ts}]$ (free variation; historically [ts]). Tones are marked as follows (using the letter $a$ as a base): high tone, $a$; mid tone, $\bar{a}$; low tone, $\dot{a}$. All syllables that end in a stop consonant $(-p,-t,-?,-k)$ are in the high tone. Open syllables without a tone mark are unstressed. A colon marks non-basic long vowels.

The data used for this chapter are from a number of different speakers, though mainly from James Khong Sar Ong and Meram Rawang, both native Mvtwang speakers from Kachin State, Myanmar. I would like to thank them for their assistance. 
(e.g. $n g \bar{a} \bar{e}$ 'to cry'), transitives, which can be used intransitively only when they take valency-reducing morphological marking (e.g. nö 'to carry (something)'); ambitransitives (labile verbs), which can be used as transitives or intransitives without morphological derivation ( $\dot{v} m \dot{\partial} \bar{e} / \bar{v} m \bar{e}$ ' to eat') ${ }^{7}$ The citation form for verbs is the 3 rd person non-past affirmative/declarative form; intransitives take the non-past affirmative/declarative particle $(\bar{e})$ alone, while transitives take the non-past 3 rd person $O$ marker $(\delta)$ plus the non-past affirmative/declarative particle $(\bar{e})$. A second difference between intransitive and transitive verbs is that in transitive clauses the agentive marker generally appears on the NP representing the A argument. ${ }^{8}$ In past-tense clauses (with 3 rd person $O$ arguments), transitives can be distinguished from intransitives by the appearance of the transitive past-tense marker $(-a)$ instead of the intransitive past-tense marker $(-i)$. We will discuss derived transitives and intransitives below."

Ambitransitive verbs are verbs that can be used either as transitives (and so take the 3rd person transitive tense markers) or as intransitives (and take the intransitive past-tense marker), without requiring any other morphological derivation. There are both $\mathrm{S}=\mathrm{O}$ types and $\mathrm{S}=\mathrm{A}$ types. With the $\mathrm{S}=\mathrm{O}$ type, as in (1), below, adding an $A$ argument creates a causative, without the need to use the causative prefix. With the $S=A$ type, use of the intransitive vs the transitive form marks a difference between a general or habitual situation and a particular situation respectively. The choice is due partly to the nature of

6 Some stative intransitive verbs can take an oblique argument marked by the locative/dative marker sing, e.g. svre 'to be afraid', where the stimulus is marked as an oblique argument:

$$
\begin{aligned}
& \text { ngà vgīsinng svrēngē } \\
& \text { ngà vgî-sving svrē-ng-ē } \\
& \text { lsg dog-LoC afraid-1 sg-N.PAST } \\
& \text { I'm afraid of dogs }
\end{aligned}
$$

${ }^{7}$ I have found one case where there are two verbs with the same meaning. one transitive and the

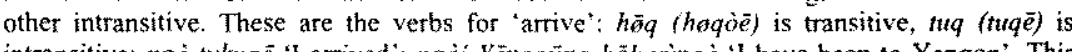
intransitive: ngà tukngè 'I arrived'; ngài Yänggüng häk yingd 'l have been to Yangon'. This shows that transitivity is a salient grammatical category in this language, unlike in many other Sino-Tibetan languages (e.g. Chinese, Lahu: see Matisoff 1976: 413 on the non-salience of transitivity as a grammatical category in Lahu).

${ }^{8}$ Morse $(1965: 348)$ analysed the appearance of the verbal suffix $-\dot{o}$ as a necessary criterion for a clause to be transitive, and so argued that only clauses with 3 rd person $O$ arguments were transitive. I have chosen to analyse this suffix as marking a 3 rd person $O$ argument (from a comparison with other dialects, it seems this form comes from the 3 rd person form of the verb 'to do'), and consider clauses that do not have $3 \mathrm{rd}$ person $\mathrm{O}$ arguments as transitive if the NP representing the $\mathrm{A}$ argument can take the agentive marker. To avoid confusion. I have generally used examples involving 3 rd person $O$ arguments in this chapter.

9 The transitive verb marking can also be added to some nouns to make transitive cognate nounverb combinations, e.g. (âng)chër chèròè 'grow wings', pvlü pvlüoè 'lay out a mat'. (Neither the causative nor applicative markers are used to make verbs from nouns.) the $O$. and partly to the nature of general vs specific action. I.e. if the $O$ is

\begin{tabular}{|c|c|c|c|c|}
\hline (1) & $\mathrm{S}=\mathrm{O}$ type & & & \\
\hline (a) & gvyaqë & 'be broken, destroyed' & gvyaq̣òē & 'break, destroy' \\
\hline (b) & gvyøpmë & "be crumpled" & gvyø:pmòè & 'crumple' \\
\hline (c) & dvtnë & 'be broken. snapped (thread)' & da:tnòē & 'break, snap' (vt) \\
\hline $\begin{array}{l}\text { (d) } \\
\text { (e) }\end{array}$ & $\begin{array}{l}\text { bvlopmẽ } \\
\text { dvchonmē }\end{array}$ & 'be folded' & bvlø:pmòē & 'fold' (vt) \\
\hline & avenopme & 'be capped' & dvcho:pmòe & 'put cap on' \\
\hline
\end{tabular}
specific, then the transitive form must be used, but if the $O$ is non-specific, it is not necessary to use the intransitive form. If no $O$ is mentioned, then usually the intransitive form is used. Some examples are given in (2):

(f) mèsògèm jaqë

mèsògèm jaq-ẽ

paper have.holes N.PAST

The paper has holes in it

(g) àngì mèsògòm jaq bèà

$$
\begin{aligned}
& \text { àng-i mèsògòm jaq bàmà } \\
& \text { 3sg-AGT paper make.holes PFV-3+TR.PAST } \\
& \text { He made holes in the paper }
\end{aligned}
$$

(2) $S=$ A type

(a) àng v̈më

àng $\bar{v}$ m-e

3 sg eat-N.PAST

He's eating / He eats

(a') à̀ngí yãlòng úmpà á:mòē

àng-i yä-lòng v́mpà v́m-ò- $\overrightarrow{\mathrm{e}}$

3sg-AGT this-CL rice eat-3+TR.N.PAST-N.PAST

$\mathrm{He}$ is eating this rice

(b) àng pé zvine

àng pé $\quad z v t-\tilde{e}$

3 sg basket weave-N.PAST

He weaves baskets (general or habitual sense)

(b') ànngi pé tiqchìng za:tnòe

$$
\begin{aligned}
& \text { àng-i pé tiq-chìng zvt-ò-ē } \\
& 3 \mathrm{sg}-\mathrm{e} \text {-A basket one-CL weave- } 3+\text { TR.N.PAST-N.PAST } \\
& \text { He is weaving a basket }
\end{aligned}
$$

Rawang seems to have only two lexical ditransitive (extended transitive) verbs: $z i$ 'give' (3a) and $\bar{v} l$ 'tell' (3b). All other ditransitive verbs, such as another form of 'tell' (3c), dvtānòe 'show' (<vtāne 'be clearly visible'), shvriòe 'send' ( $<n$ 'carry'), etc., are all derived using the causative construction (see (a) in $\$ 3.2 .1$ ). In both lexical and derived ditransitives, the Recipient 
takes Dative/Goal (Locative) marking, while the Gift is unmarked. The Donor usually takes the agentive marker. It is not possible to use the causative prefix on $z i$ 'give'; for a causative sense, the analytical causative construction must be used (see (b) in $\$ 3.2 .1$ ). There is also no construction analogous to English 'dative shift'. The order of the NPs may vary according to the information structure, but there is no change in the morphological marking.

(3) (a) Vpūngi Vdósv̀ng lègäbok ziòẽ

Vpūng-i Vdǿ-sv̀ng lègä-bok zí-ò-ë

Vpung-AGT Vdeu-LOC book-CL give-3+TR.N.PAST-N.PAST

Vpung is giving Vdeu the book

(b)

àngkaq ngà zòngsìng diám èällóé

àng-kaq ngà zòng-sving dì-ám è-v̀l-ò-é

3sg-LOC 1sg school-1.OC go-DIR N.1-tell-3+TR.N.PAST-exc

Tell him I went to school

(c) àngkaq ngà zòngsv̀ng diám wã dètáò

àng-kaq ngà zòng-sv̀ng dì-ám wā dv-è-tá-ò

3sg-LOC $1 \mathrm{sg}$ school-LOC gO-DIR COMP CAUS-N.1-hear-3+TR.N.PAST

Tell him I went to school

There are also at least three verbs that may be considered extended intransitives: mvyó 'to want, to like', vdá 'to have, to own' and 'w'a 'to say' ('see', 'look at', 'hear' and 'listen to' all pattern as normal transitives). They are always intransitive, in that they cannot take the transitive tense suffixes, and the NP representing the A argument does not take the agentive marker, but they generally take two arguments, the $A$ argument and an $O$ argument (a clause (propositional argument) in the case of mvyó and wā), neither of which takes any kind of role marking (though the initial NP can take topic marking). Examples are given in $(4):^{10}$

(4) (a) ngà kédăn lún myyóngē

ngà kédān lún mvyér-ng-ê

1 sg pen have want-1sg-N.PAST

I want to have a pen

${ }^{10}$ The verb mvyś 'to want' only takes a clausal argument. For wanting of an object rather than a propositional argument, usually the verb shong 'to love, like' is used, e.g.:

$$
\begin{aligned}
& \text { (nà) kāpà èshòngề } \\
& \text { (nà) kā-pà è-shòng-ē } \\
& \text { (2sg) Q.PN-thing N. } 1 \text {-like/love-N.PAST } \\
& \text { What do you want? }
\end{aligned}
$$

The verb $v d a$ can be used without the $O$ argument, but then has the meaning 'to be rich', (b)

ngà pūngdāngsv̀nng dī mvyóngē

ngà pv̄ngdāng-sìng dî mvyér-ng-ë

$1 \mathrm{sg}$ below-LOC go want-1sg-N.PAST

I want to go downstairs/below

(c) nöngmaq (nō) rò̀mnv̄ng àngli tiqcégé vdáiē

nöngmaq nô ròmnv̄ng àngli tiq-cé-gó vdá-i-ë

Ipl Top friend old one-ten-Cl have-Ipl-N.PAs

We have ten old friends

(d) ngà laq dī wà̄ē

ngà laq dì wä-ē

lsg should go say-N.PAST

He says I should go

The locative postposition in (4b) is on an argument of the embedded clause not the matrix clause. The matrix verb myyo follows the verb of the embedded clause directly, and no directional or other post-verbal morphology can intervene. That is, there is no tense, nominalization or person marking on the embedded clause. The intransitive nature of the verb $w a ̈$ can be seen clearly when contrasted with the homophonous verb $w a ̈$ 'to do', which is transitive:"

(4) (e) àng wàapmi

àng wà-ap-ì

3sg say-TMdys-3+iNTR.PAST

He said something $[<$ wāē $]$

(f) àngi wàapmà

àng-í wà-ap-à

3sg-AGT do-TMdys-3+TR.PAST

He did something $[<$ wäòe $]$

\section{Argument-transferring derivations}

There are a number of constructions for increasing or reducing the valency of verbs in Rawang, but there is no passive or antipassive construction.

"The verb wä 'to say' can also have the sense of a hearsay particle, as in the following two examples:

(1) nà èđi ḅ́i wäễ

nà è-dì bé-ì

I heard you went (just now)

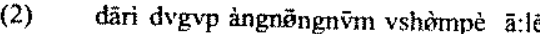

därì dvgup àngnĕngnū̄m vshŏm-pè vì

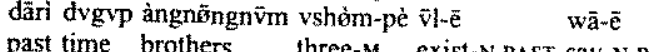

past time brothers three-M exist-N.PAST say-N.PAST

It is said that in the past there were three brothers 
3.1 Valency-reducing derivations

There are two ways that transitive verbs can be intransitivized. One is by use of the intransitivizing prefix $v$-. The other is by using the reflexive/middlemarking suffix - shi.

3.1.1 The intransitivizing prefix

The main function of the prefix $v$ - is intransitivization, as in $(5 a-b)$, but if the single direct argument of the derived intransitive is a plural animate argument, then the meaning is reciprocal, as in $(5 c-f)$ :

(5) (a) tá:lòe

tv́l-ò-ē

roll-3+TR.N.PAST-N.PAST

to roll (vt)

ngaqoe

ngaq-ò-ề

push.over-3+TR.N.PAST-N.PAST

push over

$$
\begin{aligned}
& >\text { vtv̈lë } \\
& \text { vutúl-ẽ } \\
& \text { PREF-roll-N.PAST } \\
& \text { to roll (vi) }
\end{aligned}
$$

$>$ vngaqë

$v$-ngaq-e

PREF-push.over-N.PAS

fall over

(c) àngmaq vshvtnẽ

àng-maq $v$-shvt-ē

3pl pREF-hit/kill-N.PAS

They are arguing/fighting

(d) àngmaq vyìng këe

àng-maq $v$-yving-kë-ë

$3 \mathrm{pl}$ PREF-See-RECIP-N.PAST

They are looking at each other

(e) àngmaq shàv́m këë

àng-maq shv-v-vim kë-ē

3 pl CAUS-PREF-eat RECIP-N.PAST

They are feeding each other

(f) àngmaq tāsìng tălë dà-zà-kè-ê

àng-maq tā-sìng tä-lë dì-v-zà

$k \overrightarrow{\mathrm{e}}-\ddot{\mathrm{e}}$

$3 \mathrm{pl}$ (to.each other) CAUS-PREF-feel.ill/pain RECIP-N.PAST

They are hurting each other

In $(5 \mathrm{c})$, the $v$-prefix is used alone for the reciprocal meaning. This is the normal pattern in Dulong/Rawang in general, but in the Mvtwang dialect, the verb $k \ddot{e} \sim k \dot{e}$ 'eat (meat), bite' has grammaticalized into an auxiliary reciprocal marker, and generally the two markers are used together. This usage is shown in $(5 \mathrm{~d}-\mathrm{f})$. In $(5 \mathrm{e}-\mathrm{f})$ we have a combination of the causative prefix (both allomorphs; see $\$ 3.2 .1$ (a)) and the reciprocal use of the intransitivizing prefix. See that when two non-basic prefixes combine, in this case $s h v \sim \sim d v-$ and $v-$, the result is that the vowel becomes [a-], and it takes on a full tone. In

(5f) we also have a $3 \mathrm{rd}$ marker of reciprocity, täsing tālē, a phrase meaning 'to each other'.'

The $y$-prefix can function to intransitivize in order to create something like a noun incorporation structure or to mark an unexpected or unintentional action ('just happened to ...'): ${ }^{13}$
$(6$

$$
\begin{aligned}
& \text { riỏẽ } \\
& \text { ri-ò-ẽ } \\
& \text { carry-3+TR.N.PAST-N.PAST } \\
& \text { to carry }
\end{aligned}
$$$$
\text { (7) }
$$

$>$ cùmré vrïvmi cỳmré $v$-rī-v́m-ì

child PREF-carry-DIR-3+INTR.PAST to have become pregnant

vzōmvimi

v-zöm-vंm-i

PREF-hold-DIR-3+INTR PAST

to happen to grab (as when grabbing for something when slipping down a hill)
The $v$ - prefix is also used in some cases to derive nouns from verbs, such as vngó 'someone who likes to cry a lot', from ngēe 'to cry'; $v k \dot{o}$ 'thief', from $k \bar{b} \tilde{e}-k \dot{\dot{\theta}} \dot{o} \bar{e}$ 'to steal'. ${ }^{14}$ In these cases there is also a change to high tone on the derived noun.

3.1.2 The reflexive/middle marker

The verbal suffix -shi in Rawang functions in a similar way to the reflexive construction in French, in that it marks true reflexives, as in $(8 \mathbf{a}-\mathbf{b})$, and also middles, as in $(8 \mathrm{c}-\mathrm{d})$

(8) (a) àng (nō àng) vdipshië

àng nö àng vdip-shì-ë

3sg TOP 3sg hit-R/M-N.PAST

He is hitting himself

Iy I am unclear on the meaning of $t \bar{a}$, as it only appears in this expression; sing is the locative allative/dative marker in Rawang, and $l e \tilde{~ i s ~ p o s s i b l y ~ c o g n a t e ~ w i t h ~ t h e ~ a l l a t i v e / d a t i v e ~ m a r k e ~}$ le found in some of the Dulong dialects.

As is common in Tibeto-Burman languages, the directional particles are often used to mark change of state, e.g. té-e 'big', té-lúng-i 'big-up-3+INTR. PAST' ('became big; grew up'); $d \bar{e}$ dark', dê-daq-i 'dark-down-3+INTR.PAST' ('became dark (of the sky)'); cim-é 'small', cím$a: m-i$ 'small-away-3+1NTR.PAsr' (or cim daq-i) ('became small'). It may be that in these examples what the directional particles are doing is marking a change of state, e g that in $(6)$ and (7) the meanings are closer to 'come to be baby-carrying' and 'come to be holding' respectively.

"As 'to steal' is an ambitransitive verb. it may be that the noun is derived from the intransitive form of that verb, and so the rule of $v$ - derivation would be that when the $v$ - prefix is a a transitive verb it forms a derived intransitive and when added to an intansive ford derived noun. 
3sg plastic.raincoat-INST cover-R/M-N.PAST

$\mathrm{He}$ is covering himself with a plastic raincoat

àng léshì bǿì

àng lémshì bá-i

3sg cross-R/M PFV-3.INTR.PAST

He went out.

(d)

àng vhöshiễ

àng vhö-shì $-\overline{\mathrm{e}}$

3 sg laugh/smile-R/M-N.PAst

$\mathrm{He}$ is laughing (or smiling)

In most reflexives it is possible to add a pronoun representing the $\mathrm{O}$ argument, which will be understood as coreferential with the clause-initial NP, as in (8a). The pronoun used for this is a normal pronoun; there are no special reflexive pronouns, only special emphatic pronouns, e.g. vdè 'oneself' (in the sense of 'do something oneself', not 'to oneself').

The direct reflexive and the middle are semantically similar in that one and the same referent is performing and being affected by the action, but in the case of middles these two semantic aspects of the referent or the action are not as clearly distinct as for direct reflexives. Kemmer (1993) characterizes middles as involving a 'low elaboration of participants in an event' (ch. 3), or, more generally, a 'low elaboration of events' (ch. 6) relative to direct reflexives. There is a formal difference in that for middle verbs the marking is often obligatory for a certain meaning. That is, having or not having the marker on the verb will involve a change in the meaning of the verb, e.g. le 'to cross' and cìn 'to follow' vs léshi 'to go out' and cünshi 'to leam', while with direct reflexives the addition of the marker only changes the relationship between the two participants in the action. In Dulong/Rawang the semantic types of situations that are coded with the reflexive/middle marker include those that are marked with middle-voice marking in languages that have unique middle-voice marking, e.g. Old Norse, Russian and Dutch. These types include changes in body posture, emotions, cognitive actions, grooming actions and spontaneous events. ${ }^{15}$

The reflexive/middle marking is generally added only to transitive verbs, and makes them intransitive, in that the $\mathrm{A}$ argument can no longer take the

15 See Kemmer (1993) for an in-depth discussion of middles and the categories often marked by middle marking. For more on the use of the reflexive/middle marker in Dulong/Rawang using data from the Third Township Dulong dialect, see LaPolla (1995b), and for more on middle marking in other Tibeto-Burman languages, see LaPolla (1996). agentive suffix and the verb cannot take the transitive tense markers. Though the resulting verb is intransitive, it contrasts with intransitives formed by the intransitivizing prefix $\left(v_{-}\right)$in that the verbs with the intransitive prefix express an action that is unintentional, while those marked with the reflexive/middle marker express an action that is intentional. Compare the examples in $(9 \mathrm{a}-\mathrm{c})$ with the derived intransitives in $(5 \mathrm{a}-\mathrm{c})$.

(9) (a) tv́lshië

tv́l-shì-e

roll-RM-N.PAST

to roll oneself (on purpose; intransitive, but with intentionality)

(b) ngaqshie

ngaq-shi-ẽ

push.over-R/M-N.PAST

fall over (on purpose)

(c) yüngshiē

yòng -shì-ē

see/look.at-R/M-N.PAST

look at oneself/make oneself visible, manifest oneself (such as a spirit) ${ }^{16}$

While clauses with reflexive/middle-marked verbs are formally intransitive, an unmarked NP (representing an $O$ argument) may appear in the clause, as in $(10 a-b)$ :

(10) (a) àng nāl tutshie

àng nōl tut - shì-ē

3sg fingemail cut-R/M-N.PAST

He is cutting his fingernails

(b) àng múr zv́lshiē

àng múr zv́l-shì-ē

3 sg face wash-R/M-N.PAST

$\mathrm{He}$ is washing his face

These examples represent situations that seem to be transitive events, and in languages, such as English and Chinese, that do not have middle marking and represent some middle situations with prototypical transitive forms, these examples would be coded as transitives. The possessive relationship between the $A$ argument and the bodypart must be overtly coded in English with a

${ }^{16}$ In the Dulong dialects there is a formal difference between the two meanings given for this example (which generally only holds for perception verbs). for the meaning 'look at for this only the reflexive/middle marker is used, i.e. $\mathrm{fay}^{5 s}-\mathrm{cul}^{3 i}$, while for the more sativized meaning 'be visible, manifest oneself', the intransitivizing prefix is also added to the verb, i.e $a-f a s$ s $c u u^{\prime \prime}$. If a perceiver must be mentioned in the clause, it is marked to the verb, i.e. $2-\mathrm{fan}^{55}$ postposition ( $l e^{3 t}$ in the Third Township Dulong dialect, sing in the Mvtwang dialect). 
genitive construction, as in the free translations given above. In Chinese, the relationship between the possessor and possessed bodypart is not overtly coded at all, and so must be inferred, as in the following example:

$$
\begin{aligned}
& \text { (11) wǒ yào xĩ liăn } \\
& \text { 1sg want wash face } \\
& \text { I want to wash (my) face }
\end{aligned}
$$

In Rawang, the possessor-possessed relationship must be marked by the reflexive/middle marker.

Where the $\mathrm{O}$ argument represented by the unmarked NP is not a bodypart, the referent will be understood as something that has some sort of strong connection with the referent of the $\mathrm{A}$ argument. Consider the examples in (12) to (14):

(12) (a) àng tvwìn vchaqòẽ àng tvwìn vchaq-ò-ē

3 sg snow brush-3+TR.N.PAST-N.PAST

He is brushing the snow off (something)

(b) àng tvwìn vchaqshie

àng tvwỳn vchaq-shì-ē

3 sg snow brush-R/M-N.PAST

$\mathrm{He}$ is brushing the snow off (himself)

(13) (a) à̀ngi shvmǿ sha:tnỏë

àng-i shvmǿ shvt-ò-ë

3sg-AGT mosquito kill-3+TR.N.PAST-N.PAS

He is killing a mosquito

(b) àng shvmó shvtshì

àng shvmó shvt-shì-ê

3sg mosquito kill-R/M-N.PAST

He is killing a mosquito (on him)

(14) (a) àng laq̣tūn wv̄nòè

àng laqtūn wīn-ò-

3 sg clothing buy-3+TR.N.PAST-N.PAST

$\mathrm{He}$ is buying clothing

(b) àng laqutūn wv̄nshiê

àng laqtün wv̄n-shì-ē

3 sg clothing buy-R/M-N.PAST

$\mathrm{He}$ is buying himself clothing

In these cases, the sense of the reflexive/middle is more like a benefactive, doing something For oneself rather than ro oneself. There is still an overlapping of roles on one referent, but instead of the two roles being $A$ and $O$, they are $\mathrm{A}$ and Benefactive.
In some cases there is a difference of tone on the verb in a direct reflexive situation as opposed to an indirect reflexive. In these cases a high tone marks a direct reflexive, while a mid tone marks an indirect reflexive. This can be seen by comparing the (a) and (b) examples in (15-16):

(15) (a) àng nō àng vdórshië àng nō àng vdór-shì-ẽ

3 sg Top 3 sg hit-R/M-N.PAST

He's hitting himself

(b) àng nō àng vdörshië

àng nø̄ àng vdø̄r-shì-ẽ

3 sg rop $3 \mathrm{sg}$ hit-R/M-N.PAst

$\mathrm{He}$ is hitting his own (child, etc.)

(16) (a) nà nō nà èwáshì bớ

nà nō nà è-wá-shì bó-ì

$2 \mathrm{sg}$ TOP $2 \mathrm{sg}$ N.1-do-R/M PFV-3+INTR.PAST

You did it to yourself

(b)

nà nø̃ nà èwãshì bói

nà nõ nà è-wä-shì bǿ-ì

2sg TOP $2 \mathrm{sg} \mathrm{N.1-do-R/M} \mathrm{PFV-3+INTR.PAST}$

You did it for yourself

In (15b) the form is that of a direct reflexive except for the tone on the verb, which marks the action as NoT a direct reflexive, so the object hit must be something other than the actor, but something closely related to the actor. In (16a $-b)$ again the forms differ only in terms of the tone, but this makes the difference between the actor as $\mathrm{O}$ and the actor as Benefactive (with possibly some other assumed $\mathrm{O}$ )

A subtype of this indirect reflexive is when the reflexive/middle marker is used to show an alienable possessive relationship between the $A$ and $O$ arguments, as in (17).

(17) Vpüng (nø̄) Vdø̛sv̀ng lègãbok zīshiê

Vpūng nō Vdés-sving lègā-bok zï-shì-ẽ

Vpung top Vdeu-Loc book-Cl. give-R/M-N.PAST

$\mathrm{V}$ pung gave his (own) book to Vdeu

In the case of some auxiliary verbs, the reflexive/middle marker is used on the auxiliary simply to intransitivize it to match the matrix verb in terms of transitivity. Compare the two sentences in (18).

(18) (a) à̀ngỉ shóng rimā:nòē

àng-í shóng rí-mv̄n-ò-ể

3sg-AGT tree/wood carry-continue-3+TR.N.PAST-N.PAST

$\mathrm{He}$ is continuing to carry the wood 
(b) àng yøpmūnshiē
àng yøp-mün-shì-ë
3 sg sleep-continue-R/M-N.PAs
$\mathrm{He}$ is continuing to sleep

In (18a), the main verb, rio $e^{-}$'carry', is transitive, and so the auxiliary verb, $m \bar{v} n \dot{\partial} \bar{e}$ 'continue', is also transitive, but in $(18 \mathrm{~b})$, the main verb, yopme 'sleep', is intransitive, and so münò takes the reflexive/middle marker to make it intransitive. A number of other auxiliary verbs, such as dinó 'be about to', münòe 'be used to', dìngò $\bar{e}$ 'be finished', pingò $\ddot{e}$ 'begin to' and nēò $\bar{e}$ 'be willing to', also follow this pattern. These verbs follow this pattern even with the different forms of the ambitransitive verbs, that is, when the ambitransitive main verb is used as an intransitive, the auxiliary verb takes -shi, but if the ambitransitive main verb is used as a transitive verb, then -sh is not used. Compare $(19 a-b)$, for example:

(19) (a) àng v́mdúngshì béì

àng v́m-dúng-shì bón-i

3 sg eat-finish-R/M PFV-3+INTR.PAST

He finished eating [intransitive v̈më 'eat']

(b) à:ngi v́mpàlòng v́mdv́ng bǿà

àng-í v́mpà-lòng v́m-dv́ng bá-à

3sg-INST food-CL eat-finish PFV-3+TR.PAST

He has finished eating the food [transitive imòe 'eat']

The pattern is also followed when the main verb is nominalized, as in (20)

(20) vngaqlv́m dv́nshiē

v-ngaq-lím dún-shì-ẽ

PREF-push-INF about.to-R/M-N.PAS

It seems like it is about to fall down

The reflexive/middle marker can also be used when one wants to stress that some expression represents a general situation or existing state rather than a specific event. Compare (21a) and (21b) below:

(21) (a) à̀ngí àngsìng shungōò $\bar{e}$

àng-í àng-sìng shvngō-ò- $-\bar{e}$

3sg-AGT 3sg-L.OC hate-3+TR.N.PAST-N.PAST

He hates him

(b) àng nē shvngōshië

àng nō shvngö-shì- $\bar{e}$

3 sg Top hate-R/M-N.PAS

He*s hateful
Example (21a) expresses the itea that the referent feels hate towards a specific individual, while (21b) expresses the idea that he is hateful in general, not that he hates any one person in particular. ${ }^{17}$ Compare now (22a) and (22b)

(22) (a) àng shìm pẽshie àng shìm pë-shì-ē

3sg sword hang.on.shoulder-R/M-N.PAST

$H$ is wearing a sword

(b) à̀ngí shùm péōẽ

àng-i shùm pé-ò-ē

3sg-inST sword hang.on, shoulder-3+TR.N.PAST-N.PAST

$\mathrm{He}$ is putting on or wearing a sword

In (22a), the situation is expressed as an on-going state rather than action or event, while in (22b) the action is a transitive event which could involve either the putting on or the wearing of the sword (notice in English we use two different verbs for these two meanings). There is a privative opposition between the two forms, in that the transitive form can be used for either meaning, while the reflexive/middle-marked verb has only the state-like meaning. To express the meaning 'put on' without ambiguity, it is possible to use the causative prefix (see $\$ 3.2 .1$ (a) below) together with the reflexive/middle marker, as in $(22 \mathrm{c})$ :

(22) (c) àng shv̀m dvpëshiē àng shùm $d v-p e \ddot{e}-s h i ̀-\bar{e}$

3sg sword CAUS-hang.on.shoulder-R/M*N.PAST He is putting on a sword

As discussed in LaPolla (1995a), it seems that the reflexive/middle marker may have at first been used only for direct reflexives, then came to be used more and more to express middle situations, i.e. came more and more to be associated with situations where there is a 'low elaboration of events', and then, when used on transitive verbs, came to have a function similar to that of a 'stativizer': diminishing the conceptual separation of the events and participants involved, making the overall event more like a state.

\subsection{Valency-increasing derivations}

There are six different ways that the valency of a clause can be increased in Rawang. There are two types of causative construction, an applicative

"Because this is also the refiexive form of the verb, it is ambiguous between the general meaning and the reffexive meaning, so for the reflexive meaning a second pronoun is often added after the topic marker: àng nö àng shvngöshiē 'He hates himself' 
benefactive, a $-t$ suffix, non-use of the reflexive/middle marker on 'deponent' verbs, and the use of the verb kéoe 'eat (meat), bite' as an adversative marking auxiliary verb. We will discuss each construction in turn.

\subsubsection{Causative constructions}

There are two unrelated types of causative marking: a verbal prefix (sh $\mathrm{r}^{-}$ $d v-$ ) and an analytical (periphrastic) causative construction involving the verb dvzír 'send'.

(a) The causative prefix The main morphological means for deriving causative verbs is adding the causative prefix $\left(s h v_{-}-d v^{-18}{ }^{18}\right.$ The verb in a causative involving the causative prefix can represent a state, a process or an action, and can be intransitive or transitive, but not ditransitive. A causative formed by the verbal prefix can generally be either a direct causative (actually bringing about a change of state or directly causing or helping a causee perform an action) or an indirect causative (having someone do something, but without the causer being physically involved as in the direct causative). There is no difference whether the causee is willing to perform the action or not, whether the action was accidental or not, or whether the causee is in control or not. The causative of an intransitive verb becomes a transitive verb, taking on the transitive tense marking, and the NP representing the A argument can take the agentive marking. In some cases a locative-marked argument in the intransitive takes the instrument marker in the causativized form (see $(28 a-b)$ for example). With the causative of a transitive verb, the NP representing the causer can take the agentive marker, the NP representing the $\mathrm{A}$ argument (the causee) often takes the dative/locative marker, and the $N P$ representing the $O$ argument is unmarked. The causative prefix is not used for applicatives or to derive verbs from nouns, and it is not used on ditransitives (though it is used to create ditransitives). The analytical causative ${ }^{18}$ In the Dulong dialects of Dulong/Rawang, there is clear phonetic conditioning on the two forms of the causative prefx ( initials, while su" is used before all other initals. Thave not found any such phonetic conditioning in the Rawang dialects. Thave also not found Morse's (1965: 348) statement that $d v$ - is used mainly on intransitives to be correct. One factor that may be involved is that some verbs can take both prefixes, but then only $s h v$ - has a causative meaning, while $d v$ - has the sense of 'able to [Verb]', e.g. lée 'to cross (a stream. etc.)', $d v$-lëe 'to be able to cross', shv-léoe 'make (him) cross' (it can be seen from these examples that when $d v$ - has this meaning it does not transitivize the verb). The causative prefix clearly derives from the Proto-Sino-Tibetan causativizing/transitivizing ${ }^{*} s$ - prefix (see for example Benedict 1972: $105-6 ;$ Mei 1989), but the origin of this prefix in Sino-Tibetan is not clear. The analytical causative is a relatively late development, and paralleled in many other Sino-Tibetan languages (see LaPolla 1994). construction must be used for causatives of ditransitives. There is generally no way for the verb to remain intransitive and yet have an $\mathrm{A}$ argument represented, e.g. as a peripherally marked NP. The only exception to this is the possible addition of an experiencer/perceiver argument using the locative/ dative postposition to certain derived intransitives of perception (see note 16) I have not found any particular syntactic or discourse functions associated with use of the causative aside from the semantic function of adding an $A$ argument. Following are some examples:

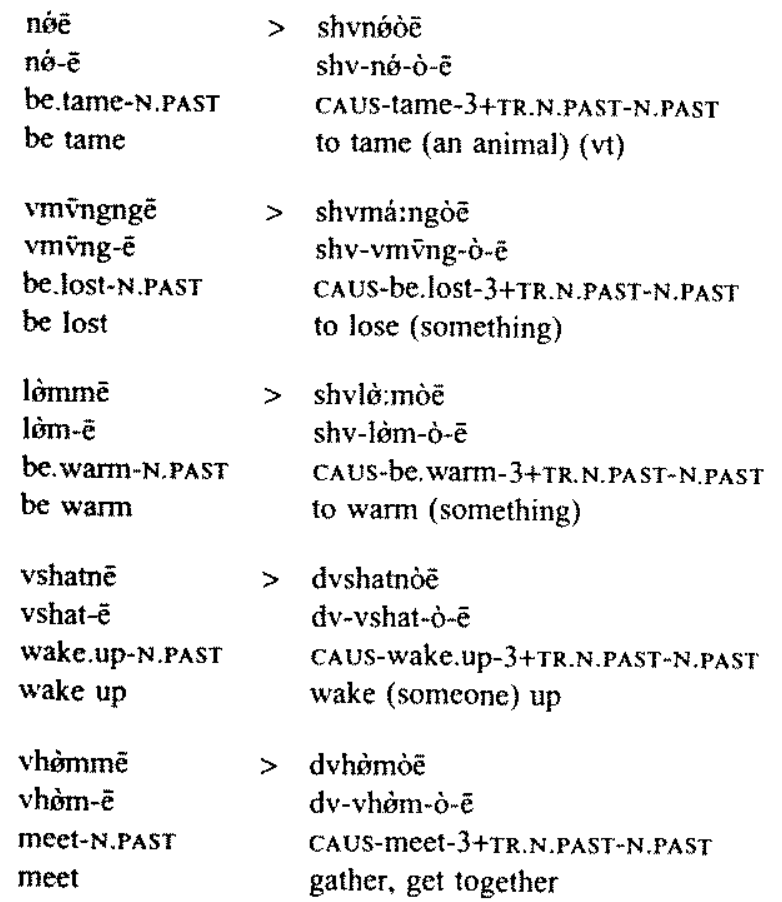

(28) (a) shvrì tiqgō tvwátaq wă api shvri tiq-gō twwá-taq wá ap-ì deer one-CL trap(n.)-Loc be.trapped TMdys-3+INTR.PAST A deer was caught in a trap

(b) shvrì tíggō tvwái shvwá apà
shvrì tiq-gō tvwá-
shv-wá
ap-à
deer one-Cl trap(n.)-INST CAUS-be.trapped TMdys-3+INTR.PAST
(He) caught a deer in/with a trap

In the causative forms in (24), (26) and (27), even though there is a combination of $\operatorname{sh} v_{-} \sim d v_{-}$and $v_{-}$, the resulting vowel is still [ə], and not [a-], as 
the $v$ - here is inherent to the root form and not a derivational prefix. Only a combination of two derivational prefixes causes the vowel change. In the intransitive (28a) ('to be caught in a trap'), the NP $t v w a$ 'trap(n.)' takes locative marking, while in the causativized version in ( $28 \mathrm{~b}$ ) ("cause to be trapped') the same NP has instrumental marking. This example also shows that cognate verbs function morphosyntactically the same as verbs formed in other ways (see note 9). Examples $(29 \mathrm{a}-\mathrm{c})$ are causatives of transitive verbs, and (29d) is an example of an intransitive verb that becomes ditransitive after causativization (the only example of this I have):

(29) (a) ... mvshūngshícèni sv̀ng dvkéòē, wä mvshv̄ng -shí-cè-ní-sv̀ng dv-ké-ò-ē human-seed-son-du-LOC CAUS-eat-3+TR.N.PAST-N.PAST say

.. (and it is said he) fed the original people (the child's flesh)

(b) ànngí Vpüng sv̀ng laqutūn dvgwāòē

àng-i Vpüng-sìng laqtūn dv-gwä-ò-e-e

3sg-AGT Vpung-LoC clothing CAUS-put.on/wear-3+TR.N.PAST-N.PAST

He made (or helped) Vpung put his clothes on

(c) àngí (àng sv̀ng) shurī mā:nòë

àng-i àng-sv̀ng shv-rī $m \bar{v} n \sim \grave{o}-\ddot{e}$

3sg-AGT 3sg-LOC CAUS-carry continue-3+TR.N.PAST-N.PAST

He makes (him) continue carrying (not 'send' here, but 'help carry')

(d) à̀ngí ngà sv̀ng Yangon dètăn yv̀ngà

àng $i \mathfrak{i}$ ngà-sv̀ng Yangon da-è-vtān

3sg-AGT lsg-LOC Yangon CAUS-N.1-visible TMyrs+1sg-3+TR.PAST

He showed me Yangon (Rangoon)

As mentioned above, generally the derived causative can be direct or indirect, but if the causation is very indirect, such as in a situation where, for example, one might be said to have 'killed' someone by not saving that person when s/he was drowning, then the word for 'cause to die' (see (30a)) would not be used directly, but would be used in a paraphrastic constnuction meaning 'it was as if I killed him', as in (30b):

\section{(30) (a) dvshóng bớngà}

dv-shí-ng bó-ng-à

CAUS-die-1sg PFV-1sg-3+TR.PAST

I caused him to die (Direct action)

$$
\begin{aligned}
& \text { ngài dvshiò dō iá:mì } \\
& \text { ngà-i dv-shí-ò dö í-ám-ì }
\end{aligned}
$$

Isg-AGT CAUS-die-3+TR.N.PAST ADV be-DIR-3+INTR.PAST

It is like I caused him to die (b) The analytical causative/permissive The analytical (phrasal) causative construction involves the use of the verb $d v z \dot{v} r$ 'send' after the main verb. This construction only has an indirect causative sense, without direct involvement of the causer, of having or letting someone do something, and the causing/letting must be purposeful, not accidental, with the causee in control, but the causee may be willing or unwilling. ${ }^{19}$ The verb involved can be intransitive, transitive or ditransitive, and generally represents an action or process that requires some effort rather than a state, for which the causative prefix is more generally used. The analytical causative can also be used together with the direct causative to express a double causative or permissive and causative. Examples of the three causative possibilities are given in (31) for intransitives and $(32 a-c)$ for transitives. The marking of noun phrases is the same as that with the causative prefix: the causer (optionally) takes agentive marking, and the causee takes the locative/allative marker (but see discussion of reflexive causatives below); (32d-e) are examples with NPs to show their marking.

(31) (a) dí dvzá:ròē

dí dvzirr-ò-ē

go send-3+TR.N.PAST-N.PAST

to let/make (him) go

(b) dvdiòe

$\mathrm{dv}-\mathrm{di}-\dot{\mathrm{o}}-\overline{\mathrm{e}}$

CAUS-go-3+TR.N.PAST-N.PAST

to make (him) go/walk

(c) dvdi dèzá:rò

dv-dí è-dìzvir-ò

CAUS-go N.1-send-3+TR.N.PAST

You let him make him go

19 There is another way to express one type of having or letting someone do something, by use of the prefix laq. This construction is formally a subtype of the imperative, and so functions differently from the analytical causative. Compare the two sentences below:

(1) Vpū:ngí bả laqdé:tò

Vpüng-i bé laq-dór-ò
Vpung-AGT rice INDTV-pound-3+TR.N.PAST

Let vpung pound the rice [imperative]

(2) Vpūingí bó dớ dèzá:ròè

Vpüng-i bó dér è-dvzír-ò-ẽ

Vpung-AGT rice pound $N$.1-send-3+TR.N.PAST-N.PAST

You let Vpung pound the rice [non-imperative] 
(32) (a) v́m dèzá:rò v́m è-dvzúr-ò eat N.1-send-3+TR.N.PAST Let him eat

\section{(b) shvá:mòē}

shv-v́m-ò-ē

CAUS-eat- $3+$ TR.N.PAST $-N . P A S T$

He feeds him

(c) shvv́m dvzá:rò

shv-v́m dvzúr-ò

CAUS-eat send-3+TR.N.PAST

Let him feed hím

(d) à̀ngi Vpūng sv̀ng mügwài dvrèrì wv̛̆m dvzá:ròē

àng-í Vpüng-sv̀ng mügwà-í dvrè-rì wv̆m

3sg-AGT Vpung-LoC raincoat-INST luggage-pl cover

dvz'́r $m \dot{\mathrm{o}}-\overline{\mathrm{e}}$

CAUS-3+TR.N.PAST-N.PAST

$\mathrm{He}$ is making Vpung cover the luggage with the raincoat

(e) à̀ngi àng sv̀ng shùm lv́ng dvza:ròē

àng-í àng-sùng shùm líng dvzúr $-\grave{a} \sim \bar{e}$

3sg-AGT 3sg-LOC knife hold CAUS-3+TR.N.PAST-N.PAST

$\mathrm{He}$ is making him hold the knife

(c) The interaction between causatives and reflexives We have looked at reflexives, and we have looked at causatives, and have seen one example $((22 c))$ of how they can be used together. In this section we discuss a few more examples to see how the two derivations interact. Compare the three examples in (33):

(33) (a) à:ngí laqtün dvshúỏē

àng- $\bar{l}$ laqtūn $d v-s h \bar{u}-\hat{o}-\bar{e}$

3sg-INST clothing CAUS-be.dry-3+TR.N.PAST-N.PAST

He is drying clothes

(b) àng dvshúshiē

ang $d v$-shü-shì-ē

3sg CAUS-be.dry-R/M-N.PAST

$\mathrm{He}$ is drying himself

(c) àng laqtün dvshūshiè

àng laquīn dv-shü-shì-ē

3sg clothing CAUs-be.dry-R/M-N.PAST

$\mathrm{He}$ is drying his clothes
In (33a) we have a causative based on the intransitive verb shïe 'be dry', with distinct $\mathrm{A}$ and $\mathrm{O}$ arguments, and it means simply that the person is drying clothes on a line or somewhere else. In (33b) we have a causative-reflexive with no other $\mathrm{O}$ argument and a high tone, so the meaning is that the person is drying him or herself, for example by standing next to a fire. In (33c) an $\mathrm{O}$ argument is mentioned, and the verb is followed by the reflexive/middle marker and has a mid tone rather than a high tone, so what is being dried is the clothing, and not the person (in a sense FoR the person), but the drying of the clothes must be while the person is wearing them.

We saw above that adding the causative prefix to a transitive verb can create an indirect causative where the causer causes (or helps) the causee perform an action that is not directed at the causer, as in (34).

(34) à:ngí Vpūng sv̀ng laqtūn dvgwäòè àng-î Vpūng-sv̀ng laqtūn dv-gwä-ò-ē

3sg-AGT Vpung-LOC clothing CAUS-put.on/wear-3+TR.N.PAST-N.PAST He made (or helped) Vpung put his clothes on

Considering only the use of the causative prefix and the reflexive/middle marker, there is then a four-way contrast:
(a) gwá-ò-ē
(b) gwā-shì-
'to put on' or 'to wear'
(c) dv-gwä-ò- $-\bar{e}$
'to wear'
(d) dv-gwā-shì-ē
'to dress someone'
'to get oneself dressed' or 'to cause/make some- one else get dressed'

The causative form, as in (34), can also be made reflexive/middle, but different dialects of Dulong/Rawang vary somewhat in what they allow. In the Third Township Dulong dialect, if the reflexive/middle-marking suffix is also added to the verb in this construction, there are two possible outcomes, depending on whether another animate referent is mentioned or assumed in the clause. Compare (35a) and (35b) (from LaPolla 1995b):

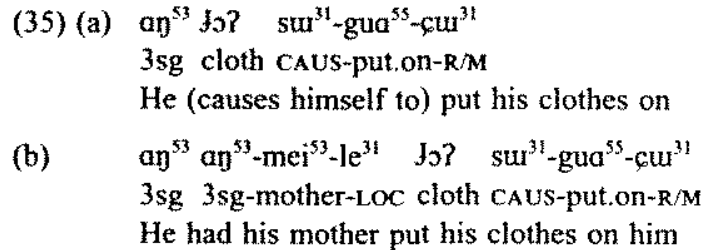

In (35a), as no other causee is mentioned or assumed, then the interpretation is that the causer causes himself or herself to perform the action, in this case, 
put clothes on. In (35b), which could be said of a small child, an animate causee is mentioned, and the reflexive/middle marker limits the interpretation of the situation to one where the action performed by the causee (which has been caused by the causer) is directed at or in some way affects the causer, not necessarily the causee.

It is also possible to add the reflexive/middle marking to a periphrastic causative construction, with the effect that the causer causes the causee to do something to him or herself, as in (36), where it is Pung's face that is to be washed:

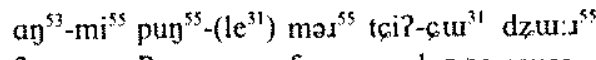

$$
\begin{aligned}
& \text { 3sg-AGt Pung-LoC face wash-R/M cause } \\
& \text { He made Pung wash his face }
\end{aligned}
$$

A second causative can also be added to a construction such as that in (36) if the verb involved is a basic intransitive, as in (37):

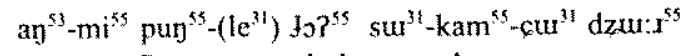

$$
\begin{aligned}
& \text { 3sg-AGT Pung-LoC cloth CaUS-dry-RM cause } \\
& \text { He made Pung dry his clothes (with Pung wearing them) }
\end{aligned}
$$

Here Pung is made to dry the clothes that he is wearing; the analytic causative expresses the idea that Pung is made to do something, while the inflectional causative expresses the idea that Pung causes the clothes to become dry, and the reflexive marker expresses the idea that the clothes being dried are the ones being worn by Pung at the time of the action.

In the Mvtwang (Rawang) dialect, the equivalent of (35a) is possible (see (38a)), but for the meaning where the causer has the causee do something to the causer, the analytical causative must be used, as in (38b).

(38) (a) àng laqtūn dvgwāshiē àng laqtūn dv-gwä-shì-ē

3 sg clothing CAUS-wear-R/M-N.PAST

He's putting his clothes on

(b) àng nō àngmèi laqtūn dvgwā dvżurshiēe
àng nō àng-mè-í laqtūn dv-gwã dvzv́r-shì-ē
3sg Top 3sg-mother-AGT clothing CAUS-wear send-R/M-N.PAST
He had his mother put his clothes on him

An interesting difference between the two dialects is that, while both dialects can express the difference between the causer having the causee doing something to the causee and the causer having the causee doing something to the causer, the way they express these two differs. In the Dulong dialect the difference between the two types of causative is in the use of the analytical causative with the reflexive/middle marker on the main verb to express the former meaning (see (36)), and the causative prefix and the reflexive/middle marker on a transitive verb for the latter meaning (see (35b)), while in the Mvtwang dialect both meanings are expressed using the analytical causative construction, with the difference being expressed by whether the reflexive/ middle marker appears on the main verb or on the causative auxiliary verb. Compare (39a) (and also (38b)) with (39b)

(39) (a) àng nō Vpūngi múr zv́l dvzúrshiē

àng nō Vpüng-í múr zúl dvzúr-shì-ē

3sg TOP Vpung-AGT face wash send-R/M-N.PAST

He is making Vpung wash his face (causer's face, not Vpung's)

(b) àngi Vpūngsìng múr zv́lshì dvzá:ròē

àng-i Vpüng-sv̀ng múr zv́l-shì dvzúr-ò-ē

3sg-AGT Vpung-1.OC face wash-R/M send-3+TR.N.PAST-N.PAST

He is making Vpung wash his (Vpung's) face

The marking of the NPs in the clause differs according to the placement of the reflexive/middle marker. The NP representing the A argument of whichever verb is not marked by the reflexive/middle marker can take the agentive marker, while the NP representing the A argument of a reflexive/middlemarked verb cannot take the agentive marker, but may take the locative/ dative marker (and may take the topic marker if it is in initial position).

The equivalent of (37) in the Mvtwang dialect is (40):

(40) à:ngí Vpūngsv̀ng laqtūng dvshūshì dvzá:ròē

$$
\begin{aligned}
& \text { àng-i Vpūng-sv̀ng laqtūng dv-shū-shì dvzvir-ò-ë } \\
& \text { 3sg-AGT Vpung-Loc clothing caUs-dry-R/M send-3+TR.N.PAST-N.PAST } \\
& \text { He is making Vpung dry his clothes (while Vpung is wearing them) }
\end{aligned}
$$

The causative can also be used with the reflexive in situations where the reflexive/middle marker indicates a possessive relation between the $A$ and the $O$ (see (17) above). In example (41), below, the reflexive/middle marker indicates the fact that the book that Vpung is letting/making Vdeu hold belongs to Vpung.

(41) Vpūng (n⿳亠㐅) Vdái lègäbok shvlv̄ngshiē

$$
\begin{aligned}
& \text { Vpūng (n̄̄) Vdó-i lègā-bok shv-lv̄ng-shì-ë } \\
& \text { Vpung TOP Vdeu-AGr book-CL CAUS-hold-R/M-N.PAST } \\
& \text { Vpung is letting Vdeu hold his book }
\end{aligned}
$$




\subsubsection{Applicative benefactive}

The only applicative construction in Rawang is the benefactive construction marked by the verbal suffix $-\bar{a}$. This form cannot be used for causative or other functions, such as for making an instrumental or locative phrase a direct argument. ${ }^{20}$ It also cannot be used for comitatives. ${ }^{21}$ The benefactive can apply to both transitives and intransitives. As adding the benefactive argument increases the transitivity of the verb, intransitive verbs become formally transitive, though the original $S$ does not take agentive marking. With transitives the old $O$ stays unmarked, and the new argument (the benefactive) is marked with the benefactive postposition $(d v p v t)^{22}$ or the locative/dative postposition sing (as with the other arguments, it may not be expressed as a noun phrase if it is recoverable from the context or person marking). Examples are given in $(42 \mathrm{a}-\mathrm{c})$ :

${ }^{20}$ Nouns representing instruments are marked with the agentive-instrumental-adverbial suffix $(-i)$, and those representing locatives with one of the locative postpositions. For alternations of the 'spray/load' type, different verbs would be used in Rawang:

(1) kvlángí mōdōchv̀ng dv̉n dvzèngòōe

kvláng-í mōdō-chv̀ng dìn dv-zèng-ò-ể

hay-INST truck-Cl fullness CAUS-full-3+TR N PAST-N.PAST

I fill the truck with hay

(2) mōdōchùngtaq kvláng dv̀n zíngòe

mōdō-chìng-taq kvláng dìn zv́ng-ò-ĕ

truck-CL-LOC hay fullness put-3+TR.N.PAST-N.PAS

I put hay onto the truck

${ }^{21}$ For comitatives, the comitative postposition ning is used. How it is used, together with the person marking on the verb, determine whether the added referent is treated as part of a single direct argument of the verb or as a separate oblique argument:

(1) ngà àngnìng rüngë

ngà àng-nìng rüng-ë

Isg 3 sg-Comit sit-N.PAsT

(2) ngà nv̀ng àng tiqdö rúngshiē

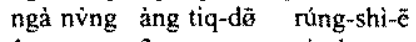

Isg COMIT 3 sg one $A$ ADV sit-du-N.PAST

He and $\mathrm{I}$ are sitting together

In (1), the comitative postposition appears after the second NP, and the verb agreement is singular, while in (2) the comitative postposition comes between the two NPs and the verb agreement is dual.

${ }^{22}$ The benefactive postposition can sometimes be used without adding the benefactive suffix to the verb, as in the following example:

yākōng vimpà nŏ vshìmgó dvp̣t luqẽ

yā-kōng vmpà nö vshèm-gá dvpvt luq -ë

this-CI rice TOP three-Cl for be.enough-N.PAST

This bowl of rice is enough for three people
(42) (a) ngài (àng-sìng/dvpvt) shóng rớngāngòë

ngà-i àng-sv̀ng/dyput shêng rí-ng-ă-ng-ò-ẽ

$1 \mathrm{sg}$-AGT $3 \mathrm{sg}-\mathrm{LOC} / \mathrm{for}^{23}$ wood carry-1 sg-BEN-1sg-3+TR.N.PAST-N.PAST I'm carrying wood for him

(b) àng dvpvt rumáhíng shvláảōè

àng dvpvt rvmá-híng shvlá-ā-ò-ë

3 sg for field-field be.good-BEN-3+TR.N.PAST-N.PAST

The fields are good for him

(c) àngtaq yãdùng bèlaq mvnoklá téāòẽ

àng-taq yä-dùng bèlaq mvnøklá té-ā-ò-ê

$3 \mathrm{sg}-\mathrm{LOC}$ this-CL upper.garment too be.big-BEN-3+TR.N.PAST-N.PAST

This shirt is too big for him

If there is an auxiliary verb, such as münd̀ 'to continue' or dingöë 'to finish", then the benefactive suffix appears after the auxiliary verb, as in $(42 d)$ :

(42) (d) à̀ngí rímv̄năòē

àng-i rímv̄n-ä̀-ò-e

3 sg-AGT carty-continue-BEN-3+TR.N.PAST-N.PAST

He continues carrying for someone else

In some cases the benefactive suffix has the meaning 'instead of', as in (43). If the name of the person in whose place the action is performed needs to be mentioned, then it is followed by either the benefactive postposition (dvpvt) or by $w \vec{l} \vec{e}$ 'exchange'.

(43) (Vpüng tvlë) àngsv̀ng ngø̄tnāngòè
Vpūng tvlè
àng-sv̀ng ngø̄t-ā-ng-ò-ề
Vpung exchange $3 \mathrm{sg}-\mathrm{LOC}$ mourn-BEN-1sg-3+TR.N.PAST-N.PAST
$I$ mourn him (instead of Vpung mourning him)

Although the suffix $-\tilde{a}$ generally has the function of adding a benefactive argument, in two cases from the Rawang Creation Story and one elicited example the use of the suffix does not seem to have the meaning of doing the action 'for someone', but more the sense of possession. These are given in (44):

${ }^{23}$ This postposition is only used for the benefactive sense of English for; the purposive sense of for in, for example, 'I work for money' is expressed by $n t$ 'because' of: gùmsùng rvt bìnlì wīngè

money for work do-lsg-N.PAS

I work for money 
(44) (a) shv̄ngbēí vgö vshvpmã yà:ngà rvt vpú vgō vdv́mēe, wäē shv̈ngbë-í vgō vshvp-ā yàng-à rvt vpú vgō all-AGT head rub-BEN TMyrs-3+TR.PAST because owl head vdv́m-ë wä-ẽ flat-N.PAST SAy-N.PAST

It is said that because everyone rubbed his head (rubbed him on the head after he said something wise), the owl's head is (now) flat

(b) vnö dvbø̛p húm gö èlv̄māòē

vnö dvbøp hv́m ḡ̄ è-lv̄m-ā-ò-ē

bean rotten basket also N.1-step.on-BEN-3+TR.N.PAST-N.PAST

You stepped on (someone's) basket of fermented beans

(c) yābok lègā kāgé íāòē

yă-bok lègă kä-gá îa

this-CL book Q.PN-CL be-BEN-3+TR.N.PAST-N.PAST

Who does this book belong to?

In (44a), vshvp 'rub' could have been used without the $-\vec{a}$ suffix and have basically the same meaning. It seems that the benefactive suffix is used here because the actual direct argument (which could be marked by the locative/ dative marker sing) is $v g \bar{o}$ 'head', but the person/animal to whom the head belongs is affected as well. In (44b), the benefactive is used to emphasize that the deer stepped on someone else's beans. In $(44 \mathrm{c})$ the benefactive suffix makes the copula transitive, giving it the sense of 'this belongs to' rather than 'this is'.

Aside from the applicative benefactive, there are other ways that a benefactive sense is accomplished. We saw above that the reflexive/middle marker in some cases has a benefactive sense, though it is unlike the applicative benefactive in that it is transitivity-reducing and limited to cases where the benefactive and the $\mathrm{A}$ are the same referent. The benefactive in that construction cannot take the benefactive postposition ( $d v p v t)$.

A thitd type of benefactive that is also a type of indirect reflexive developed from the grammaticalization into auxiliary verbs of the two words for 'to eat': $\bar{v} m(\hat{o}) \bar{e}$ 'to eat (rice, vegetables)', $k \bar{e}(\dot{o}) \bar{e}$ 'to eat (meat), bite'. These verbs are used after the main verb for an indirect reflexive sense when the action expressed by the main verb relates to doing something to or with a domestic animal $(k \bar{e})$ or non-animal food $(\vec{v} m)$ that is eaten. The auxiliary verbs follow the pattern of transitive for specific actions and intransitive for general or regular, continuing actions (such as actions done for one's livelihood; see $\$ 2$, and noted in (b) below). This is also a type of benefactive, but not applicative, as it does not increase the transitivity of the clause. Following are examples of this usage with different types of activities.
(45) (a) àng kwá tiqyòm róng kēē àng kwá tiq-yòm róng

$3 \mathrm{sg}$ bee one-hive put.in.hole eat-N.PAST ${ }^{24}$

He is raising bees for himself

(b) àng waq näkēē

àng waq nã-kē-ế

3 sg pig feed-eat-N.PAST

He feeds the pigs for himself ${ }^{25}$

(c) àng ngā mit kề-ë

àng ngä mit $k \bar{e}-\tilde{e}$

$3 \mathrm{sg}$ fish catch eat-N.PAST

He catches fish for himself

(d) àng láv̄mē

àng láa-ìm-è

3sg cut.down-eat-N.PAST

He cuts down (banana trees) to get the fruit for himself

(e) ti kvpmùm á:miē

ti $\quad k v p-$ vim ám-i-ë

water get-eat DIR-Ipl-N.PAST

We go get water for ourselves

(f) ngàmaq yúng kvtná:mì

ngàmaq yúng $\quad k v t-\bar{v} m-i$

lpl vegetables grow-eat- $1 \mathrm{pl}$

We grow vegetables for ourselves

(g) àng v́mpà wv̄nūmē

àng v́mpà $\quad$ wพvn-v̄m-

3 sg rice/food buy-eat-N.PAST

$\mathrm{He}$ is buying himself rice/food ${ }^{26}$

24 The larvae of the bees are eaten, so këë and not $\bar{m} m \vec{e}$ is used; the verb róng 'put in a hole' is 25 used because bees are raised in a hole in a tree.

25 Compare this example with (45b):

à:ngi waq nākëèē

àng-i waq nä̃-kē- $\dot{b}-\bar{e}$

3sg-AGT pig feed-eat-3+TR.N.PAST-N.PAST

$\mathrm{He}$ is feeding the pigs (right now)

Here, as the main verb is used transitively (due to the fact that it is a specific action/event

rather than a general one), the auxiliary is also transitive. ${ }^{26}$ Contrast this with the use of the reflexive/middle marker for the same situation, but involving
non-edible objects:

ngà laquūn wv̈nshòngë

ngà laquiun wv̄n-shi-ng-ë

Isg clothing buy-R/M-1 Sg-N.PAST

1 am buying myself clothes 
(h) àng n⿳亠े wãv̄mē

àng nò wä-v̈m-

3 sg wine make/do-eat-N.PAST

$\mathrm{He}$ is making wine for himself

In terms of the benefactive sense, there is then a four-way contrast:

(a) kvtshie 'to grow something (not eaten) for oneself' (reflexive)

(b) kvtnūmēe 'to grow something (eaten) for oneself' (food-benefactive)

(c) kvtnāòe 'to grow something for someone else' (benefactive)

(d) vkvtnā kēe 'to grow something for one another' (reciprocalbenefactive)

3.2.3 Transitivization by addition of final $-t$

A second form of transitivization is not productive. This is transitivization by the addition of a final $-t$ to an intransitive form. I have only one example of this type, though I believe there should be other examples, as this form of transitivization is found in closely related languages, such as Jinghpaw, and is an old Sino-Tibetan trait (see Dai and Xu 1992; Benedict 1972: 98-102; Michailovsky 1985; van Driem 1988)

(46) (a) ngēē 'to cry' > ngøt-ò- $-\overline{\mathrm{c}}$ 'to cry over/mourn someone'

(b) ngài àng ngøtnòē

ngà-í àng ngø-t-ò-ë̀

1sg-AGT 3sg cry-transitivizer-3+TR.N.PAST-N.PAST

I am crying over (mouming) him

\subsubsection{Other ways of increasing transitivity}

There are two other ways that the transitivity of a verb can be increased. One is by NoT using the reflexive/middle marker on a verb for which the reflexive/ middle form is the statistically unmarked form. This has the same effect as the applicative in some other languages. For example, vhëshie 'laugh' has the middle as its statistically unmarked form, even though it has the intransitivizing prefix and the reflexive/middle-marking suffix, while the formally unmarked (but statistically marked) form hōò 'laugh at someone' (e.g. àngi àngsìng $h \bar{\partial} \dot{\partial} \bar{e}$ 'He is laughing at him') is statistically and semantically more marked.

In situations where there is an adversative sense of something happening to someone that is beyond their control, the verb kéò 'eat (meat), bite' can be used, often with the causative prefix as well, and this can make the sentence partly transitive, as in $(47 \mathrm{a}-\mathrm{c})$. It is only partly transitive because there is no A argument that can take the agentive marker (though in some cases there is an instrumental argument, as in $(47 \mathrm{c})$ ), as the cause of the action is generally unknown. Semantically then, it is like a passive in emphasizing affectedness and lack of control, but syntactically it is not valency-reducing, the way passives are.

\section{(47) (a) àng dvgøq kèòē} àng dv-geq ké-ò-ë

3sg CAUS-hiccup eat-3+TR.N.PAST-N.PAST

He's hiccuping (uncontrollably) (normally àng gøqë)

(b) (pòyaq) chapgá (gá) cv̀mré shvngé kéōē

pòyaq chapgá gá cìmré shv-ngé kè-ò-ē

all,night morning bright child CAUS-cry eat-3+TR.N.PAST-N.PAST

The children are / have been crying (all night) until morning (light)

(c) àng vléí mvdŏng kéòe

àng vléri mvdèng ké-ò- $-\bar{c}$

3sg vlé-1NST stuck eat-3+TR.N.PAST N.PAST

He has vé stuck in his throat (vlé is a kind of rough food)

This usage is actually a subtype of a more general usage of the verb $k \dot{e}-k \bar{e}$ 'eat (meat), bite' for an adversative sense shown in (48). It can be used for any situation where the speaker has a negative attitude towards the referent involved in the action/situation or the action/situation itself. This can be used to show empathy with someone suffering a negative situation, and so is said to be more polite in some instances, such as $(48 \mathrm{~d})$, and also has something of a passive sense, emphasizing affectedness (e.g. (48a), where the word order marks the receiver of the scolding as the topic). In these cases the form of the verb is always transitive.

(48) (a) àng(sv̀ng) vpèi ngv̄n kéòē

àng-sv̀ng v-pè-i ngv̄n kè-ò-ēe

3sg-LoC 1 -father-AGT scold eat-3+TR.N.PAST-N.PAST

He is being scolded by my father

(b)

àng svmïi gáng kéòẽ

àng svmĩmí gáng ké-ò-ēe

3 sg fire-iNST hot eat-3+TR.N.PAST-N.PAST

He's hot from the fire

(c) à̀ngi pàgō mà-shvbờn kéò

àng-i pà-go mà-shv-bỏn ké-ò

3sg-AGT thing-also NEG-CAUS-be.possible eat-3+TR.N.PAST

He's incapable of doing anything

(d) àngsv̀ng tvp ké bǿà

àng-sìng tvp ké bó-à

3sg-LOC be.arrested eat PFV-3+TR.PAST

He was arrested 
(e)

$$
\begin{aligned}
& \text { àng nō nò mvnøklá aq dári rvt (nèi) vrù kéòē } \\
& \text { àng nø̆ nò mvnøklá aq dăr-ì rvt nò-i } \\
& \text { 3sg Top wine too drink TMhrs-3+INTR.PAST because wine- } \\
& \text { vù̀ ké-ò-ē } \\
& \text { drunk eat-3+TR.N.PAST-N.PAST } \\
& \text { He drank too much and so is/got drunk (from the wine) }
\end{aligned}
$$

\section{Conclusions}

We have seen that in Rawang, unlike in many other Sino-Tibetan languages, the coding of transitivity and the use of transitive vs intransitive constructions to convey different meanings are important aspects of the grammar. Aside from the different uses of the two forms of ambitransitive verbs, there are two morphological means for decreasing the valency of clauses, and six means for increasing their valency. We have also seen that a speaker may employ several different valency-increasing and valency-decreasing morphemes in the same clause to achieve different meanings through their interaction.

\section{References}

Barnard, J.T.O. 1934. A handbook of the Rawang dialect of the Nung language. Rangoon: Superintendent of Government Printing and Stationery.

Benedict, P.K. 1972. Sino-Tibetan: a conspectus (J.A. Matisoff, contributing ed.). New York: Cambridge University Press.

Dai Qingxia, Huang Bufan, Fu Ailan, Renzengwangmu and Liu Juhuang. 1991. ZàngMiănyŭ shiwŭ zhöng (Fifteen Tibeto-Burman languages). Beijing: Yanshan Chubanshe.

Dai Qingxia and Xu Xijian. 1992. Jingpöyü yrifa (The grammar of the Chinghpaw language). Beijing: Zhongyang Minzu Xueyuan Chubanshe.

Driem, G. van. 1988. "Reflexes of the Tibeto-burman *-t directive suffix in Dumi Rai', pp. 157-67 of Prosodic analysis and Asian linguistics: to honour R.K. Sprigg, ed. D. Bradley, E.J.A. Henderson and M. Mazaudon, Pacific Linguistics C 104. Canberra: Australian National University.

Kemmer, S. 1993. The middle voice, Typological studies in language 23. Amsterdam and Philadelphia: John Benjamins.

LaPolla, R.J. 1994. 'Parallel grammaticalizations in Tibeto-Burman: evidence of Sapir's "drift"', Linguistics of the Tibeto-Burman Area 17.61-80.

1995a. 'On the utility of the concepts of markedness and prototypes in understanding the development of morphological systems', Bulletin of the Institute of History and Philology (Academia Sinica) 66.1149-85.

1995b. 'Reflexive and middle marking in Dulong/Rawang.' Paper presented to the 28th International Conference on Sino-Tibetan Languages and Linguistics.
Charlottesville, Va., 6-9 October. To appear in Himalayan linguistics, ed. G. van Driem. Berlin: Mouton de Gruyter.

1996. 'Middle voice marking in Tibeto-Burman languages.' Pan-Asian linguistics: proceedings of the Fourth International Symposium on Languages and Linguistics. Vol. V. Thailand: Mahidol University.

Liu Juhuang. 1988. 'Dúlóngyǔ dòngci yánjiü (Studies on the Dulong verb)'. Yǔyán yánjiū 1988.1.176-91.

Lo Ch'ang-p'ei. 1945. 'A preliminary study of the Trung language of Kung Shan', Harvard Journal of Asiatic Studies 8:343-8.

Matisoff, J.A. 1976. 'Lahu causative constructions: case hierarchies and the morphology/syntax cycle in a Tibeto-Burman perspective', pp. 413-42 of The syntax of causative constructions, ed. M. Shibatani. New York: Academic Press.

Mei Tsu-lin. 1989. 'The causative and denominative functions of the *s- prefix in Old Chinese.' Proceedings of the Second International Conference on Sinology. Taipet: Academia Sinica.

Michailovsky, B. 1985. 'Tibeto-Burman dental suffixes: evidence from Limbu (Nepal)', pp. 334-43 of Linguistics of the Sino-Tibetan area: the state of the art. Papers presented to Paul K. Benedict for his 71 st birthday, ed. G. Thurgood, J.A. Matisoff and D. Bradley, Pacific Linguistics C 87. Canberra: Australian National University.

Morse, R.H. 1963. 'Phonology of Rawang', Anthropological Linguistics 5.17-41.

1965. 'Syntactic frames for the Rvwang (Rawang) verb', Lingua 15.338-69.

Sun Hongkai. 1982. Dúlóngyũ jiănzhi (A sketch of the Dulong language). Beijing: Minzu Chubanshe.

1988. 'Notes on a new language: Anong', Linguistics of the Tibeto-Burman Area 11.27-63. 